\title{
A Micro Analysis of the Infant Mortality Decline in an Italian Sharecropping Community from 1900 to 1939
}

\author{
By Francesco Scalone \\ Patrizia Agati ${ }^{\dagger}$ \\ Aurora Angeli \\ Annalisa Donno
}

In the first decades of the twentieth century, an evident reduction of the infant mortality rate occurred in Italy. In previous studies, less attention has been devoted to the effects of individual bio-demographic and socioeconomic components on infant mortality. We use micro data from births, deaths and marriages civil registers of Granarolo, an Italian rural municipality close to Bologna, from 1900 to 1939. We are able to reconstruct some typical bio-demographic characteristics and the socioeconomic status of parents. In these terms, the analysis includes: parity, age of the mother, previous birth interval and child survival, father's occupations and literacy, season and year of birth. Cox and Piecewise constant exponential models are used to estimate the effects of the selected predictors. We found that still in the first four decades of the twentieth century rural daily wagers experienced a lower level in infant survivor, whereas the upper class registered significantly higher ones.

\section{Introduction and Aim of the Paper}

In the first decades of the twentieth century, an evident reduction of the infant mortality rate occurred in Italy. Previous studies already demonstrated the existence of significant variations at a regional level, showing the importance of geographical and environmental factors. Since these studies were mainly based on macro aggregated data, less attention has been devoted to the effects of individual bio-demographic and socioeconomic components on infant mortality. However to improve the knowledge of the infant mortality decline in Italy, we need to compare the roles of the bio-demographic and socioeconomic characteristics. How were these components related to the infant mortality decline? To answer this question, our analysis adopts a micro analytical approach taking into account individual data and using multivariate statistical methods.

Several studies on both historical and contemporary populations already showed the significant influence of the bio-demographic and physiological

\footnotetext{
* Assistant Professor, Department of Statistical Sciences, University of Bologna, Italy.

$\dagger$ Associate Professor, Department of Statistical Sciences, University of Bologna, Italy.

* Professor, Department of Statistical Sciences, University of Bologna, Italy.

Associate Researcher, Department of Statistical Sciences, University of Padova, Italy.
} 
factors. According to these findings, infant mortality risks could be related to male neonates, multiple births and very young or old mothers. Besides that, in the developing countries, evidences for the maternal depletion hypothesis were also provided, registering higher risks of infant mortality for higher parities and shorter intervals between consecutive births ${ }^{1}$. The effects of environmental and climatic factors such as the season of birth were also assessed. By using micro data and studying Italian communities in nineteenth century, higher risks of infant deaths were observed for the poorest sectors of the rural population. However, less attention has been provided to the first half of the twentieth century that was a period of strong social and economic transformations in both the rural and urban areas. Therefore, we aim to investigate and compare the roles of bio-demographic and socio-economic determinants of infant mortality in the first decades of the twentieth century.

So we use micro data from births, deaths and marriages civil registers, to study infant mortality at the individual level in Granarolo, an Italian rural municipality close to Bologna, from 1900 to 1939 . By using the traditional method of family reconstitution, we are able to take into account the typical bio-demographic characteristics and the socio-economic status of the parents of each neonate. In these terms, the analysis includes: sex of the newborns, multiple births, age of the mother, previous birth interval and survivor of the last child, father's occupations and literacy, season and year of birth. Kaplan Meier curved and generalized linear models are used to estimate the effects of the selected predictors on infant mortality.

In the next section of this paper, we briefly compare the historical trends in infant mortality in Italy and European countries. Then we present the area under study, focusing on the socio-economic context and the infant mortality levels. After having described the source and the data used, the statistical methods and the multivariate statistical models are presented, listing the covariates and discussing their expected effects. Finally, we present and discuss the empirical results.

\section{Historical Trends in Infant Mortality in Italy and European Countries}

Trends in infant mortality in Europe between 1860 and 1940 underline dramatic differences among countries, both in the initial level of the rate and in decreasing trends (Figure 1). During the second half of the nineteenth century Italy showed a higher level of infant mortality with respect to other countries of northern and western Europe. The rates fluctuated from 125-150 deaths before the first birthday in Sweden to 225-230 in Italy that showed levels similar to

1. Julie DaVanzo, Lauren Hale, Abdur Razzaque and Mizanur Rahman, "The effects of pregnancy spacing on infant and child mortality in Matlab, Bangladesh,; How they vary by the type of pregnancy outcome that began the interval," Population Studies 62, no 2(2008): 131154. 
those of Germany or other eastern European countries as Russia, Hungary or Romania $^{2}$.

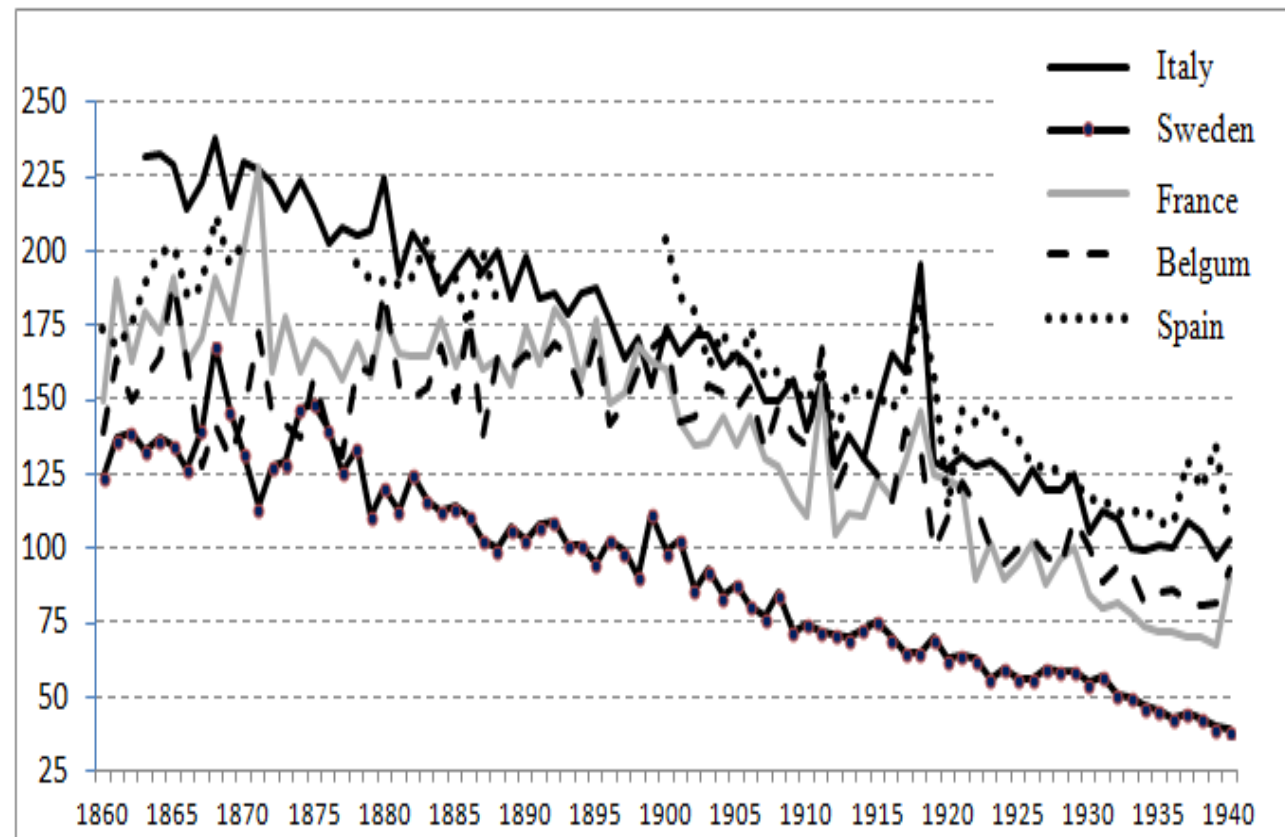

Figure 1. Infant Mortality Rates (per 1,000 live births) in Italy and Selected European Countries 1860-1940

Source: Mitchell 1975

Trends in infant mortality immediately after National Unification - as in general for total mortality - reflect the Italian delay in the processes of socioeconomic development in life conditions of the population and the persistence of mass marginalization ${ }^{3}$.

In the last years of the nineteenth century the Italian level of infant mortality approached the levels of France and England: around 170 per 1,000 live births versus 150 and $160^{4}$.

The decline in infant mortality from the beginning of the twentieth century (around 1900) seems to be a universal phenomenon in Europe. For Italy also a decreasing trend became more and more marked and faster than in other European countries, with the exception of the period including the World War I and the Spanish influenza in 1919.

2. Brian R. Mitchell, European Historical Statistics 1750-1970 (London: McMillan Press, 1975).

3. Athos Bellettini, "Aspetti della transizione demografica italiana nel primo periodo postunitario" [Features of the Italian demographic transition during the first post-unification period], in Studi in onore di Luigi Del Pane (Bologna: CLUEB, 1981), 769-805.

4. Lorenzo Del Panta, "Infant and child mortality in Italy, eighteenth to twentieth century: long-term trends and territorial differences" in Infant and Child Mortality in the Past, ed. Alain Bideau, Bertrand Desjardins, and Héctor Pérez Brignoli (Oxford: Claredon, 1997), 7-21. 
The long term decrease of these series suggests that it could be correlated with the improvements in the socio-economic environment as well as with new measures realized in the health sector ${ }^{5}$. During the nineteenth century Italy registered a new interest towards life conditions of the proletarian classes. Inside this new interest emerged also a rise in the attention towards early childhood health problems, in particular among pediatricians. The debate on poverty and pauperism developed in Italy from the nineteenth century underlined, amongst an extensive assortment of problems, the worse conditions of motherhood and childhood. It emerged the need of public care interventions, including the protection of child health and surviving.

\section{The Analyzed Area}

\section{The Socio-Economic Context}

Granarolo is a rural municipality situated in the northern part of the suburban hinterland of Bologna. The area of Bologna lies on the Po River valley, and is crossed by the main transportation routes between the south and the north of Italy. This position made Bologna an important center of commerce and manufacturing activities, thus influencing the economy of the surrounding area.

During the period under analysis, Granarolo was mostly populated by two main socio-economic groups: farmers, small landowners and sharecroppers, and agricultural wage laborers.

Sharecroppers lived in a large complex-family household. All household members worked on the farm, including women and children who, beyond being in charge with household activities, worked in fields, generally dealing with the less demanding tasks. Sharecroppers' households were characterized by high levels of self-sufficiency, guaranteed by their properties or by their sharecropping contracts. Moreover, a better access to familial networks, offering material and emotional support, as well as practical information during critical life moments, guaranteed assistance and security for all family members ${ }^{6}$.

The wage labors households, instead, lived in nuclear, isolated families, facing severe housing conditions. Both men and women served as wage laborers. With low wages and an uncertain number of workdays during the year, they lived precariously, rarely well-nourished and always exposed to the risk of illness that often reduced them to penury ${ }^{7}$.

5. Franco Della Peruta, "Infanzia e famiglia nella prima metà dell'Ottocento," Studi Storici 20, no 3 (1979): 473-491.

6. Maura Palazzi, "Famiglia, lavoro e proprietà: le donne nella società contadina fra continuità e trasformazione" [Family, labor and property: women in rural society between continuity and change], Annali dell'Istituto Alcide Cervi 12 (1990): 25-80.

7. Stefano Jacini, I risultati della Inchiesta Agraria (1884). La situazione dell'agricoltura e dei contadini italiani dopo l'Unità [Results from the agrarian survey (1884). The situation of 
From the beginning of the Twentieth century, the traditional sharecropping economy steadily reduced due to the development of large-scale, capitalistic agriculture that made the daily wagers' conditions more unstable and precarious 8 .

In the same period, the area was progressively transformed by important socio-economic processes, such as urbanization and the first phases of industrialization. Sharecroppers' households reacted to those changes creating an economic system in which farming was combined with work in the industrial sector ${ }^{9}$. However, despite the substantial socio-economic and political transformations, the proportion of sharecroppers living in the rural area of Bologna did not significantly decrease and remained quite stable ${ }^{10}$.

\section{Infant Mortality Trends}

During the first half of the twentieth century, Emilia-Romagna experienced progressive improvements in survivor conditions: life expectancy at birth for both genders grew from 43 years in 1901 to 68 years in 1951, while infant mortality steadily declined above all because of the reduction in neonatal mortality ${ }^{11}$. Infant mortality decreased in the region going from about $170 \%$ in $1901-1910$ to about $81 \%$ in the 1930 s. In the same period the neonatal mortality rate declined from about $78 \%$ o to about $42 \%{ }^{12}$.

Infant mortality rates were lower in the province of Bologna with respect to those registered in the whole Emilia-Romagna region. They fluctuated from $230-270 \%$ in the last decades of the nineteenth century, to $84 \%$ in most of the 1930s. Differences were due to better geographic-environmental conditions ${ }^{13}$ and to improvements in obstetrical assistance and infant care, already advanced

agriculture and the Italian farmers' conditions after Unification], (Torino: Giulio Einaudi Editore, 1884).

8. Daniela Calanca, "Famiglia e famiglie" [Family and families], in Identikit del Novecento: conflitti, trasformazioni sociali, stili di vita, ed. Paolo Sorcinelli, (Roma: Donzelli Editore, 2004), 97-179; Franco Cazzola, Storia delle campagne padane dall'Ottocento a oggi [History of the Po country sides from the 1800s until today] (Milano: Bruno Mondadori Editore, 1996).

9. Pasquale Villani, "La pluriattività negli spazi rurali: ricerche a confronto. Introduzione" [Pluriactivity in rural areas: researches comparisons. Introduction]," Annali dell'Istituto Alcide Cervi 11, (1989): 11-22.

10. Athos Bellettini, "Aspetti della transizione demografica italiana nel primo periodo postunitario" [Features of the Italian demographic transition during the first post-unification period], in Studi in onore di Luigi Del Pane (Bologna: CLUEB, 1981), 769-805.

11. Lucia Pozzi, "The determinants of infant and childhood mortality: a complex tangle in the historical research," in Società Italiana di Statistica, Atti della XLI Riunione Scientifica, Milano 5-7 giugno (Padova: CLEUP, 2002), 77-86.

12. Istituto Centrale di Statistica, "Tendenze evolutive della mortalità infantile in Italia [Infant mortality evolving trends in Italy]," Annali di statistica, VIII (1975), 29. Roma.

13. Aurora Angeli, Lorenzo Del Panta and Alessandra Samoggia. 1995. "Aspetti del regime demografico in Emilia-Romagna tra XVIII e XIX secolo [Features of the demographic regime in Emilia-Romagna between XVII and XIX century]," in Le Italie demografiche. Saggi di demografia storica, ed. Lorenzo Del Panta, (Udine: Università degli Studi di Udine, 1995), 123-150. 
in the early nineteenth century ${ }^{14}$. The first Italian chair in obstetrics was instituted in 1804 at the University of Bologna; obstetric-gynaecological clinics were established in 1860 in two hospitals (Ospedale Sant'Orsola and Ospizio Esposti), that promoted the reduction of stillbirths and perinatal risk ${ }^{15}$, and brought to the diffusion of better knowledge on maternal practices such as breastfeeding and weaning. Historical sources referred to the nineteenth century record the attention of hospital pediatricians towards rural children's health and the presence of midwives in the area under analysis. During the period under study from 1900 to 1939, the infant mortality rate in Granarolo was equal to $96.8 \%$, a lower level than both regional and national averages. The rising interest towards maternal and child health, together with better housing conditions could have protected rural women and newborn health, thus contributing to lower children early mortality.

\section{Data and Methods}

\section{Municipality Sources and Family Reconstruction}

Data used for the analysis are the result of a retrospective reconstruction process, focusing on newborns in families and their survival history, during the first year of life. The main data sources used for the individual biographies and family reconstitution ${ }^{16}$ have been the civil status registers available in the demographic office of the municipality of Granarolo. They report, in different volumes created on an annual base, births, marriages and deaths occurred in the municipality, since 1866 till nowadays.

Specifically, the birth registers include the name and surname of the newborn, date and place of birth, sex, parents' name and occupation, type of delivery (single or multiple births) and legitimacy status. A useful source of information in the birth registers are the hand written marginal annotations reporting, beside the birth details, information on stillbirths and immediate neonatal death after childbirth (not reported in the death register). In all these cases, a note is observed, reporting that the newborn was not alive at the moment of the registration, without specifying whether he or she was stillbirth

14. Francesco Scalone, Patrizia Agati, Aurora Angeli and Annalisa Donno, "Microanalisi delle tendenze nella mortalità infantile a Granarolo dell'Emilia tra il XIX e il XX secolo [Micro Analysis in Infant Mortality Trends in Granarolo between XIX and XX Century]," in Mortalità e stato di salute dalla nascita alla prima adolescenza. Indagini micro in Italia. Secoli XIX-XX, ed. Marco Breschi and Lucia Pozzi. (Udine: Forum 2013), 51-79.

15. Peter Ward, "Perinatal mortality in Bologna, 1880-1940," in The Determinants of Infant and Child Mortality in Past European Populations, ed. Marco Breschi and Lucia Pozzi, (Udine-Sassari: Forum, 2004), 213-230.

16. Michel Fleury and Louis H. Henry, Des registres paroissiaux à l'histoire de la population: Manuel de dépouillement et d'exploitation de l'état-civil ancien [Church records to the history of the population: Manual of count and exploitation of former civil status] (Paris: INED, 1956); John E. Knodel, Demographic behavior in the past: A study of fourteen German village populations in the Eighteenth and Nineteenth centuries (Cambridge: Cambridge University Press, 1988) 
or live-born, as in other Italian municipalities ${ }^{17}$. The procedure of marginal annotations was not systematically performed but provides - when present important additional information on perinatal deaths ${ }^{18}$. The signature of the father at the end of the birth registration, made the deduction of both its presence and literacy also possible.

Marriage registers inform on the date of marriage, spouses' name and surname, their age, place of birth and place of residence, names of each spouse parents. Death registers collect information on date of death, name and surname, place of birth and residence, parents' name and surname.

The absence of the individual's date of birth in the death registers made the record linkage between birth and death registers necessary, on the basis of both the individual's name and surname and the name and surname of the parents, in order to compute the newborn age at death.

The obtained dataset has subsequently been linked to the marriages register for obtaining information on parity, mother's age at childbirth, and sibling birth interval. This approach allowed collecting information on single individuals and on their family features. This additional information made possible to consider, for each individual, which familial variables may have had some effect on his/her survival. At the end, this analysis takes into account 4,826 live births and 467 infant deaths within 365 days of life.

\section{Survival Models}

Kaplan-Meier non-parametric estimates of the survival function $S(t)$, that describe the probability of survival past time (age, in days) $t$, were computed to estimate time-to-event for the available data ${ }^{19}$. A number of patterns of survival rates over time were displayed as survival curves and log-rank tests were used to test the null hypothesis of no difference between survival functions across groups $^{20}$.

To assess the effect of the observed factors on infant mortality, a Cox Proportional (CP) hazard model was estimated ${ }^{21}$ :

$\lambda_{i}(t)=\lambda_{0}(t) \exp \left(\boldsymbol{x}_{i}^{\prime} \boldsymbol{\beta}\right)$

or, linearizing by taking the logarithm:

17. Marco Breschi, Massimo Esposito, Stanislao Mazzoni, and Lucia Pozzi, "The Sardinian Experience of the lowest Italian infant mortality at the turn of the twentieth century. True or false empirical evidence? " Annales de démographie historique 1, (2012): 63-94.

18. Using the date (and hours) of childbirth reported in the birth registration, it was possible to understand that these cases only concerned stillbirths and early neonatal deaths occurred within two days of delivery.

19. Edward L. Kaplan and Paul Meier, "Nonparametric estimation from incomplete observations," Journal of the American Statistical Association 53 (1958): 457-481.

20. Nathan Mantel and William Haenszel, "Statistical aspects of the analysis of data from retrospective studies of disease," Journal of the National Cancer Institute, 22(1959): 719-748.

21. Davis R. Cox, "Regression Model and life tables," Journal of Royal Statistical Society, Series B (Methodological), 34 (1972), 187-220. 
$\log \lambda_{i}(t)=\log \lambda_{0}(t)+\boldsymbol{x}_{i}^{\prime} \boldsymbol{\beta}$

where

- $\lambda_{i}(t)$ is the hazard rate of death for an infant $i$ at duration (age) $t$;

- $\lambda_{0}(t)$ is the baseline hazard at duration $t$, that is, the hazard function for an infant having the value 0 on all covariates;

- $\boldsymbol{x}_{i}^{\prime}=\left(x_{i 1}, \ldots, x_{i k}, \ldots, x_{i K}\right)$ is the $K$-dimensional vector of the individual covariates in the model;

- $\quad \boldsymbol{\beta}$ is the $K$-dimensional vector of parameters to be estimated from the data.

To better control for infant age, a Piecewise-constant Exponential (PCE) hazard model $^{22}$ was also used, that is a proportional hazards model with constant baseline hazards within pre-specified time intervals. It assumes that:

- $n$ individuals are observed over a time period divided into $J$ intervals, with cutpoints $0=\tau_{0}<\tau_{1}<\ldots<\tau_{J}<\infty$;

- the baseline hazard $\lambda_{0}(t)$ is constant within each interval $j$, for $j=1,2$, $\ldots, J$ : in symbols, $\lambda_{0}(t)=\lambda_{j}>0$ for $t$ in $\left[t_{j-1}, t_{j}\right)$.

As it is easy to realize, these constant time period-specific hazard rates, instead of the whole-range rates of the Cox model, are equivalent to having time period specific intercept terms in the overall hazard. Introducing the vector of predictors $\boldsymbol{x}_{i}^{\prime}$, the hazard rate for the $i$ th subject in the $j$ th interval is

$\lambda_{i j}=\lambda_{j} \exp \left(\boldsymbol{x}_{i}^{\prime} \boldsymbol{\beta}\right)$

or, taking the logarithm of both sides:

$$
\log \lambda_{i j}=\alpha_{j}+\boldsymbol{x}_{i}^{\prime} \boldsymbol{\beta}
$$

where $\alpha_{j}=\log \lambda_{j}$ gives the constant $\log$ hazard within time interval $j$ for the baseline group.

It is worth noting that the PCE model, that can be shown to be equivalent to a Poisson regression model, is a semi-parametric continuous time duration model: the shape of the hazard rate is not specified a priori but is determined by the data.

All statistical analyses were performed using Stata 12 (College Station, TX: StataCorp LP).

22. Michael Friedman, "Piecewise exponential models for survival data with covariates," The Annals of Statistics 10, no1 (1982):101-113. 


\section{Variables}

To assess the main determinants that influence the probability of infant mortality in Granarolo, the models include the child's individual and biological variables, behavioral and socio-economic characteristics of the child's parents.

For the newborn we consider sex, single or multiple deliveries, birth interval, season of birth. In both historical and current developing populations, biological factors induce higher mortality risks for male infants during the first year of life ${ }^{23}$. Multiple births - inducing lower birth-weight - are strongly negatively related with infant survival ${ }^{24}$. Also short preceding birth intervals according to the maternal depletion hypothesis - have been found to increase the risk of infant mortality ${ }^{25}$.

Moreover, our previous results showed that winter born children had the greatest risk of infant mortality ${ }^{26}$, in line with other analysis on northern and central Italy ${ }^{27}$.

To synthesize the parental child's parents we include other three covariates: mother's age and working status, father's socio-economic status and his presence and ability to sign.

The mother's age emerges from the literature as a relevant determinant of infant mortality, even if not in a linear relationship: higher levels of infant mortality correspond to children of very young mothers and for those born to older mothers ${ }^{28}$.

23. Greg. L Drevenstedt, Eilleen Crimmins, Sarinnapha Vasunilashorn, and Finch Caleb, "The rise and fall of excess male infant mortality," Proceedings of the national academy of sciences of the United States of America 105, no13 (2008): 5016-5021.

24. Rathavuth Hong, "Effect of multiple birth on infant mortality in Bangladesh," Journal Paediatrics Child Health 42, no10 (2006): 630-635; Edward A. Wrigley, Davis S. Ros, James E. Oeppen, and Roger S Schofield, English population history from family reconstitution 1580-1837( Cambridge: Cambridge University Press, 1997).

25. Julie DaVanzo, Lauren Hale, Abdur Razzaque and Mizanur Rahman, "The effects of pregnancy spacing on infant and child mortality in Matlab, Bangladesh: How they vary by the type of pregnancy outcome that began the interval," Population Studies 62, no 2(2008): 131154; World Health Organization (WHO), Neonatal and perinatal mortality. Country, regional and global estimates. France, 2006.

26. Francesco Scalone, Patrizia Agati, Aurora Angeli and Annalisa Donno, "Microanalisi delle tendenze nella mortalità infantile a Granarolo dell'Emilia tra il XIX e il XX secolo [Micro Analysis in Infant Mortality Trends in Granarolo between XIX and XX Century]," in Mortalità e stato di salute dalla nascita alla prima adolescenza. Indagini micro in Italia. Secoli XIX-XX, ed. Marco Breschi and Lucia Pozzi. (Udine: Forum 2013), 51-79.

27. Marco Breschi, Derosas Renzo and Matteo Manfredini, "Infant mortality in Nineteenth-century Italy: Interactions between ecology and society," in Population and economy. From hunger to modern economic growth, ed. Tommy Bengtsson, and Osamu Saito (Oxford: University Press, 2000); Renzo Derosas, "The joint effect of maternal malnutrition and cold weather on neonatal mortality in nineteenth-century Venice: An assessment of the hypothermia hypothesis," Population Studies 63, no3 (2009): 233-251.

28. Karen L Kramer and Jane B. Lancaster, "Teen motherhood in cross-cultural perspective," Annals of Human Biology 37, no5 (2010): 613-628; Lucia Pozzi, "The determinants of infant and childhood mortality: a complex tangle in the historical research, in Società Italiana di Statistica," in Atti della XLI Riunione Scientifica, Milano 5-7 giugno (Padova: CLEUP, 2002), 77-86. 
We assume the mother's occupation as a proxy of the women's conditions during pregnancy. Moreover, the father's occupation synthesizes the socioeconomic status of the newborns' household, expecting a close connection with infant mortality ${ }^{29}$. The categorical variable "father presence at birth's registration and his ability to sign the document" further specifies the father's social status.

Finally, we also include five different decades of birth, to capture the changes in mortality over time.

Table 1. Descriptive Statistics for Variables Included in the Analysis: Percentage Distribution

\begin{tabular}{|c|c|c|c|}
\hline & 1900-1939 & 1900-1919 & 1920-1939 \\
\hline \multicolumn{4}{|l|}{ Sex of newborn child } \\
\hline Male & 50.8 & 49.9 & 52.0 \\
\hline Female & 49.2 & 50.1 & 48.1 \\
\hline \multicolumn{4}{|l|}{ Multiple births } \\
\hline Single & 97.2 & 97.0 & 97.6 \\
\hline Twins & 2.8 & 3.0 & 2.4 \\
\hline \multicolumn{4}{|l|}{ Age of mother } \\
\hline$<25$ & 26.3 & 22.6 & 30.9 \\
\hline $25-29$ & 24.8 & 25.1 & 24.5 \\
\hline $30-34$ & 18.1 & 19.7 & 16.0 \\
\hline$>34$ & 16.2 & 19.2 & 12.3 \\
\hline Unknown & 14.7 & 13.4 & 16.3 \\
\hline \multicolumn{4}{|l|}{$\begin{array}{l}\text { Previous birth interval and } \\
\text { child survival }\end{array}$} \\
\hline First birth or uknown & 44.8 & 42.1 & 48.1 \\
\hline$<19$ months and alive & 8.4 & 9.6 & 6.8 \\
\hline$<19$ months and death & 2.3 & 2.9 & 1.7 \\
\hline$>=19$ months and alive & 40.2 & 40.7 & 39.6 \\
\hline$>19$ months and death & 4.4 & 4.8 & 3.9 \\
\hline \multicolumn{4}{|l|}{ Season } \\
\hline Winter & 25.5 & 26.5 & 24.3 \\
\hline Spring & 25.9 & 25.4 & 26.6 \\
\hline Summer & 23.6 & 22.5 & 25.0 \\
\hline Autumn & 24.9 & 25.7 & 24.1 \\
\hline \multicolumn{4}{|l|}{ Period } \\
\hline 1900-1909 & 30.1 & 53.9 & \\
\hline $1910-1914$ & 15.5 & 27.7 & \\
\hline $1915-1919$ & 10.3 & 18.4 & \\
\hline
\end{tabular}

29. Breschi Marco, Renzo Derosas and Matteo Manfredini, "Infant mortality in Nineteenth-century Italy: Interactions between ecology and society," in Population and economy. From hunger to modern economic growth, ed. Tommy Bengtsson, and Osamu Saito (Oxford: Oxford University Press, 2000). 


\begin{tabular}{|l|c|c|c|}
\hline 1920-1929 & 25.5 & & 57.8 \\
\hline 1930-1939 & 18.7 & & 42.2 \\
\hline Socioeconomic Status & & & \\
\hline Professionals, clerical and sales & 5.6 & 4.3 & 7.1 \\
\hline Skilled and lower skilled workers & 23.1 & 20.1 & 26.9 \\
\hline Farmers & 47.6 & 48.9 & 45.9 \\
\hline Rural daily wagers & 20.9 & 25.1 & 15.6 \\
\hline Unknown & 2.9 & 1.6 & 4.5 \\
\hline Mother's rural status & & & \\
\hline Mother not in rural work & 40.5 & 37.9 & 43.8 \\
\hline Mother in rural work & 59.5 & 62.1 & 56.2 \\
\hline Father's literacy & & & \\
\hline Sign & 81.8 & 75.5 & 89.7 \\
\hline No sign & 12.1 & 18.6 & 3.8 \\
\hline Father not present & 6.1 & 5.9 & 6.4 \\
\hline No. of births & 4,826 & 2,693 & 2,133 \\
\hline
\end{tabular}

Source: Birth, Marriage and Death Registers of the Municipality of Granarolo

\section{Results}

Kaplan Meier survival curves are displayed (Figure 2) by socio-economic status, mother's rural status, period and season, respectively. It is possible to see that the children of daily wagers register lower survival levels from their early days of life. 


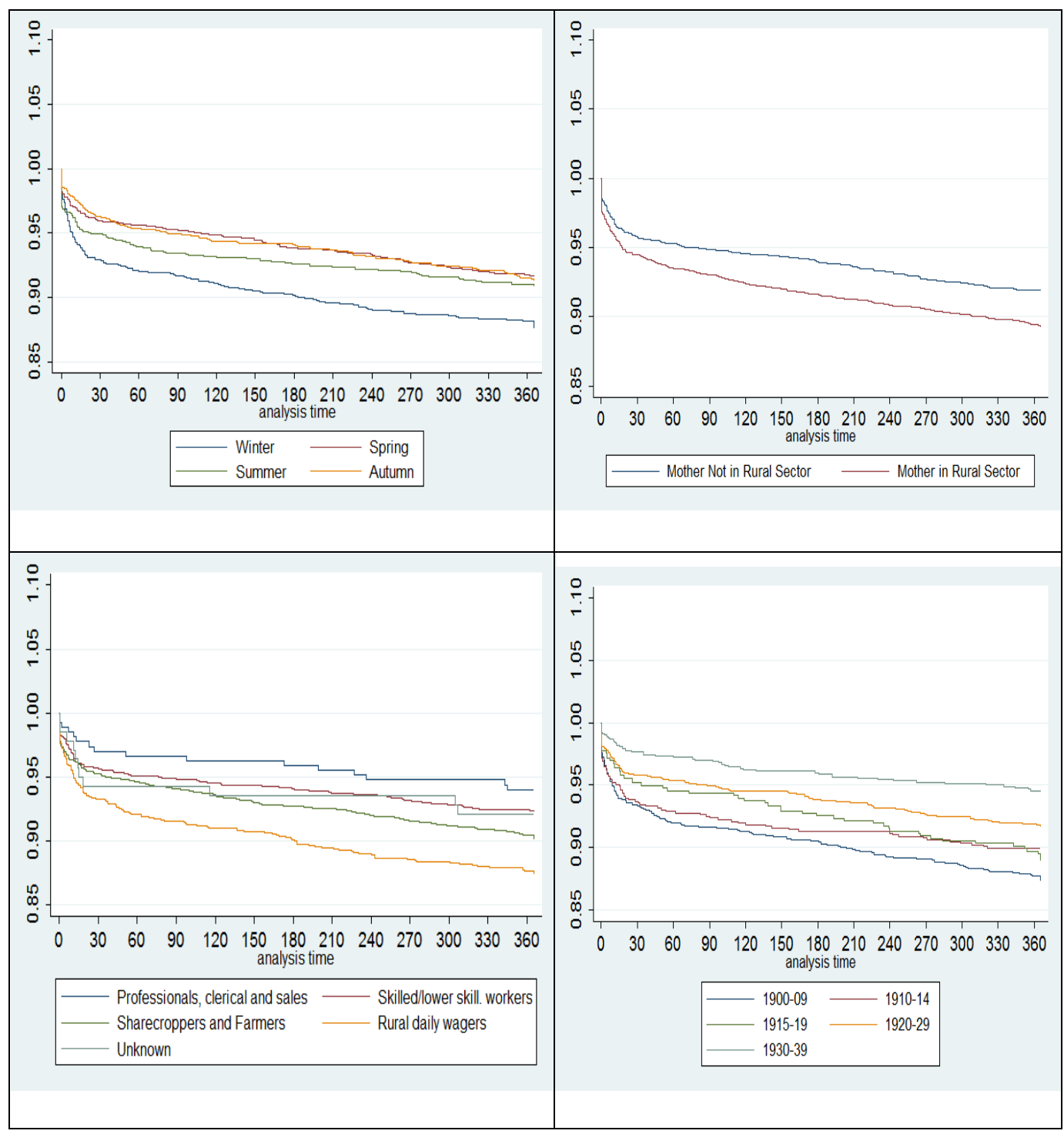

Figure 2. Kaplan Meier Survival Curves by Socio-Economic Status, Mother's Rural Status, Period and Season

Sources: Birth, Marriage and Death Registers of the Municipality of Granarolo.

Their Kaplan Meier curve declines more evidently after the first neonatal period, whereas the well-off group is constantly on higher levels. The survivor functions of the other socio-economic categories ("Skilled and lower skilled workers", "Farmers and Sharecroppers" and "Unknown") remain on very similar levels. One year (365 days) after childbirth, the rural daily wager's neonates have a 0.87 survivor probability, whereas the upper class registers a higher level (0.94). The log-rank test in table 2 confirmed the statistical significance of these differences.

It is also possible to see the effects of further socio-economic differences taking into account the working sector of the mother (rural or not rural one). Considering the Kaplan Meier curves (figure 2), the neonates of rural working 
mothers always register lower survivor probability than the other group. The statistical significance of this difference is also assessed by the means of the log-rank test (table 2). Taking into account the survivor estimates by period of birth, as expected, the neonates born in the first period from 1900 to 1909 have the lowest survivor level, whereas the newborns in the most recent decade 1930-1939 register higher survivor probabilities (see also the log-rank test at table 2). The World War I does not seem to have any impact on the infant mortality, since the survivor curves for the two periods 1910-1914 and 19151919 appear on very similar levels.

Tabel 2. Log-Rank Test for Equality of Survivor Functions

\begin{tabular}{|l|r|r|r|r|}
\hline & Socioeconomic Status & Mother's rural status & Period & Season \\
\hline Chi 2 & 19.74 & 8.98 & 36.32 & 15.22 \\
\hline df & 4.0 & 1.0 & 4.0 & 3.0 \\
\hline Pr>chi2 & 0.001 & 0.003 & 0.000 & 0.002 \\
\hline
\end{tabular}

Source: Birth, Marriage and Death Registers of the Municipality of Granarolo.

Looking at the Kaplan Meier curves by season (figure 2) it is also evident that the neonates born during the winter experienced the lowest levels of survivorship during the entire neonatal and infant period, whereas the neonates born in springtime and autumn were characterized by higher values. These differences are also statistically significant (table 2). Newborns in summer were on intermediate levels. These neonates probably suffered because their rural mothers were involved in the harvest carrying out heavy physical works. At 180 days after childbirth, less than $90 \%$ of the newborns in winter are still alive, while the survivor proportion for neonates in summer and autumn is about $94 \%$. After the first year of their life (365 days), only the $87 \%$ of the winter's neonates are alive, whereas this estimate is between 91 and $92 \%$ for the other seasons.

Estimates of Cox models are presented for the period 1900-1939 and the two subperiods 1900-1919 and 1920-1939 in table 3. Looking at these estimates for the period from 1900 to 1939, bio-demographic effects like multiple births, sex and maternal age are statistically significant. These effects also appear in the expected directions, with lower risks of infant mortality for female neonates and higher ones for twins and older maternal age. Because of the limited number of cases, only multiple births register fully significant effects for both periods 1900-1919 and 1920-1939, whereas maternal age and sex of newborn assumes a statistical significance respectively for the first period and the latter one. Considering the 1920-1939 period, a higher risk of infant death is registered for previous birth interval shorter than 19 months with the last child dead.

The seasons have also significant effects on infant mortality. Looking at the model estimates for the entire 1900-1939 period, we can observe lower risks of death during the spring, summer and autumn compare to winter. The effect of spring is not significant for the first period (1900-1919), whereas summer has no significance for the latter interval (1920-1939). 
With respect to the socio-economic status of the father, well off and higher status group has a 45 per cent lower probability of infant mortality than rural daily wagers (table 3, model for the period from 1900 to 1939). It is likely that we could rely on better infant care and childrearing in the first life. No significant effect results for the father's literacy, whereas the "father not present" category significantly increases the infant mortality risk. In these terms, the presence of the father could make some differences during the infants' life. Considering the period effects (still table 3), the two decades after World War I show a significant decline in infant mortality risks.

Table 3. Cox Model Analysis of the Risk of Infant Mortality in Granarolo, 1900-1939

\begin{tabular}{|c|c|c|c|c|c|c|c|c|c|}
\hline & \multicolumn{3}{|c|}{ 1900-1939 } & \multicolumn{3}{|c|}{ 1900-1919 } & \multicolumn{3}{|c|}{ 1920-1939 } \\
\hline & RR & SE & $p$ & RR & SE & $p$ & RR & $\mathrm{SE}$ & $p$ \\
\hline \multicolumn{10}{|l|}{$\begin{array}{l}\text { Sex of newborn } \\
\text { child }\end{array}$} \\
\hline Male (Ref.) & 1.000 & - & - & 1.000 & - & - & 1.000 & - & - \\
\hline Female & 0.817 & 0.076 & 0.031 & 0.886 & 0.101 & 0.289 & 0.664 & $\begin{array}{r}0.11 \\
1\end{array}$ & 0.014 \\
\hline \multicolumn{10}{|l|}{ Multiple births } \\
\hline Single (Ref.) & 1.000 & - & - & 1.000 & - & - & 1.000 & - & - \\
\hline Twins & 4.448 & 0.727 & 0.000 & 4.396 & 0.860 & 0.000 & 4.978 & $\begin{array}{r}1.52 \\
5 \\
\end{array}$ & 0.000 \\
\hline \multicolumn{10}{|l|}{ Age of mother } \\
\hline$<25$ & 1.174 & 0.169 & 0.266 & 1.159 & 0.208 & 0.410 & 1.215 & $\begin{array}{r}0.29 \\
8\end{array}$ & 0.427 \\
\hline 25-29 (Ref.) & 1.000 & - & - & 1.000 & - & - & 1.000 & - & - \\
\hline $30-34$ & 1.297 & 0.192 & 0.079 & 1.237 & 0.220 & 0.231 & 1.514 & $\begin{array}{r}0.40 \\
4 \\
\end{array}$ & 0.120 \\
\hline$>34$ & 1.363 & 0.208 & 0.043 & 1.427 & 0.254 & 0.046 & 1.154 & $\begin{array}{r}0.35 \\
9 \\
\end{array}$ & 0.646 \\
\hline Unknown & 1.341 & 0.214 & 0.067 & 1.241 & 0.248 & 0.281 & 1.525 & $\begin{array}{r}0.41 \\
3 \\
\end{array}$ & 0.119 \\
\hline \multicolumn{10}{|l|}{$\begin{array}{l}\text { Previous birth } \\
\text { interval and } \\
\text { child survival }\end{array}$} \\
\hline $\begin{array}{l}\text { First birth or } \\
\text { uknown }\end{array}$ & 0.988 & 0.161 & 0.941 & 0.857 & 0.158 & 0.404 & 1.479 & $\begin{array}{r}0.51 \\
9 \\
\end{array}$ & 0.265 \\
\hline $\begin{array}{l}<19 \text { months and } \\
\text { alive (Ref.) }\end{array}$ & 1.000 & - & - & 1.000 & - & - & 1.000 & - & - \\
\hline $\begin{array}{l}<19 \text { months and } \\
\text { death }\end{array}$ & 1.224 & 0.374 & 0.508 & 0.850 & 0.317 & 0.663 & 3.221 & $\begin{array}{r}1.80 \\
1 \\
\end{array}$ & 0.037 \\
\hline $\begin{array}{l}>=19 \text { months } \\
\text { and alive }\end{array}$ & 0.813 & 0.135 & 0.214 & 0.738 & 0.140 & 0.111 & 1.141 & $\begin{array}{r}0.40 \\
5\end{array}$ & 0.711 \\
\hline $\begin{array}{l}>19 \text { months and } \\
\text { death }\end{array}$ & 0.873 & 0.235 & 0.614 & 0.672 & 0.218 & 0.222 & 1.807 & $\begin{array}{r}0.91 \\
3 \\
\end{array}$ & 0.242 \\
\hline \multicolumn{10}{|l|}{ Season } \\
\hline Winter (Ref.) & 1.000 & - & - & 1.000 & - & - & 1.000 & - & - \\
\hline Spring & 0.680 & 0.087 & 0.002 & 0.790 & 0.119 & 0.118 & 0.450 & $\begin{array}{r}0.10 \\
9 \\
\end{array}$ & 0.001 \\
\hline Summer & 0.744 & 0.095 & 0.020 & 0.680 & 0.110 & 0.017 & 0.823 & $\begin{array}{r}0.17 \\
5 \\
\end{array}$ & 0.359 \\
\hline Autumn & 0.696 & 0.089 & 0.004 & 0.689 & 0.108 & 0.018 & 0.695 & $\begin{array}{r}0.15 \\
6 \\
\end{array}$ & 0.104 \\
\hline \multicolumn{10}{|l|}{$\begin{array}{l}\text { Socioeconomic } \\
\text { Status }\end{array}$} \\
\hline $\begin{array}{l}\text { Professionals, } \\
\text { clerical and sales }\end{array}$ & 0.555 & 0.157 & 0.037 & 0.526 & 0.205 & 0.099 & 0.586 & $\begin{array}{r}0.24 \\
8 \\
\end{array}$ & 0.207 \\
\hline $\begin{array}{l}\text { Skilled and lower } \\
\text { skilled workers }\end{array}$ & 0.816 & 0.138 & 0.229 & 0.787 & 0.165 & 0.252 & 0.819 & $\begin{array}{r}0.24 \\
2\end{array}$ & 0.499 \\
\hline $\begin{array}{l}\text { Sharecroppers } \\
\text { and Farmers }\end{array}$ & 0.847 & 0.097 & 0.147 & 0.856 & 0.115 & 0.244 & 0.807 & $\begin{array}{r}0.18 \\
2\end{array}$ & 0.342 \\
\hline
\end{tabular}




\begin{tabular}{|c|c|c|c|c|c|c|c|c|c|}
\hline $\begin{array}{l}\text { Rural daily } \\
\text { wagers (Ref.) }\end{array}$ & 1.000 & - & - & 1.000 & - & - & 1.000 & - & - \\
\hline Unknown & 0.775 & 0.262 & 0.451 & 0.296 & 0.220 & 0.101 & 1.167 & $\begin{array}{r}0.47 \\
1\end{array}$ & 0.702 \\
\hline \multicolumn{10}{|l|}{$\begin{array}{l}\text { Mother's rural } \\
\text { status }\end{array}$} \\
\hline $\begin{array}{l}\text { Mother not in } \\
\text { rural work (Ref.) }\end{array}$ & 1.000 & - & - & 1.000 & - & - & 1.000 & - & - \\
\hline $\begin{array}{l}\text { Mother in rural } \\
\text { work }\end{array}$ & 1.257 & 0.162 & 0.077 & 1.236 & 0.194 & 0.177 & 1.299 & $\begin{array}{r}0.29 \\
9 \\
\end{array}$ & 0.256 \\
\hline \multicolumn{10}{|l|}{ Father's literacy } \\
\hline Sign (Ref.) & 1.000 & - & - & 1.000 & - & - & 1.000 & - & - \\
\hline No sign & 1.145 & 0.154 & 0.313 & 1.107 & 0.163 & 0.488 & 1.382 & $\begin{array}{r}0.48 \\
4 \\
\end{array}$ & 0.356 \\
\hline $\begin{array}{l}\text { Father not } \\
\text { present }\end{array}$ & 1.169 & 0.256 & 0.477 & 1.805 & 0.481 & 0.027 & 0.558 & $\begin{array}{r}0.24 \\
2\end{array}$ & 0.178 \\
\hline \multicolumn{10}{|l|}{ Period } \\
\hline 1900-1909 (Ref.) & 1.000 & - & - & 1.000 & - & - & & & \\
\hline 1910-1914 & 0.836 & 0.117 & 0.201 & 0.820 & 0.115 & 0.158 & & & \\
\hline $1915-1919$ & 0.874 & 0.144 & 0.417 & 0.770 & 0.137 & 0.142 & & & \\
\hline 1920-1929 & 0.718 & 0.093 & 0.010 & & & & 1.000 & - & - \\
\hline 1930-1939 & 0.477 & 0.079 & 0.000 & & & & 0.670 & $\begin{array}{r}0.11 \\
8 \\
\end{array}$ & 0.023 \\
\hline $\begin{array}{l}\text { Number of } \\
\text { events }\end{array}$ & 467 & & & 314 & & & 153 & & \\
\hline $\begin{array}{l}\text { Number of } \\
\text { childbirths }\end{array}$ & 4,826 & & & 2,693 & & & 2,133 & & \\
\hline Log likelihood & $-3,863.7$ & & & $-2,419.0$ & & & $-1,137.9$ & & \\
\hline Days at risk & $1,633,110.5$ & & & $895,184.5$ & & & $737,926.0$ & & \\
\hline
\end{tabular}

Sources: Birth, Marriage and Death Registers of the Municipality of Granarolo.

Turning to the piecewise constant exponential model (table 4), the estimates consider the total period 1900-1939 and the two sub-periods (19001919 and 1920-1939) again. These models consider the same covariates already included in the Cox regression analysis. In addition these models also control the infant age by means of a categorical variable (0-6 days of life, 7-30, 31-180 and 181-365). The piecewise constant exponential analysis confirms the results of the Cox model, since the magnitude of the effects and their statistical significances appear on the same levels. Looking at the effects of the infant age, the risk of death is highest in the first week of life for all the three estimated models. Furthermore, the mortality risks decline evidently in the following ages, showing a progressive reduction respect to the first week of life (the reference category): $-84 \%$ between 7 and 30 days, $-96 \%$ between 31 and 180 and $-98 \%$ between 181 and 365 (see the model for the period from 1900 to 1939 at table 4). 
Vol. 2, No. 1 Scalone: A Micro Analysis of the Infant Mortality Decline in an...

Table 4. Piecewise Constant Exponential Model Analysis of the Risk of Infant Mortality in Granarolo, 1900-1939

\begin{tabular}{|c|c|c|c|c|c|c|c|c|c|}
\hline & \multicolumn{3}{|l|}{ 1900-1939 } & \multicolumn{3}{|l|}{ 1900-1919 } & \multicolumn{3}{|c|}{ 1920-1939 } \\
\hline & RR & SE & $p$ & RR & SE & $p$ & RR & SE & $p$ \\
\hline \multicolumn{10}{|l|}{$\begin{array}{l}\text { Sex of newborn } \\
\text { child }\end{array}$} \\
\hline Male (Ref.) & 1.000 & - & - & 1.000 & - & - & 1.000 & - & - \\
\hline Female & 0.819 & 0.077 & 0.032 & 0.889 & 0.101 & 0.303 & 0.663 & 0.111 & 0.014 \\
\hline \multicolumn{10}{|l|}{ Multiple births } \\
\hline Single (Ref.) & 1.000 & - & - & 1.000 & - & - & 1.000 & - & - \\
\hline Twins & 4.646 & 0.760 & 0.000 & 4.605 & 0.902 & 0.000 & 5.174 & 1.588 & 0.000 \\
\hline \multicolumn{10}{|l|}{ Age of mother } \\
\hline$<25$ & 1.177 & 0.169 & 0.257 & 1.163 & 0.209 & 0.400 & 1.224 & 0.301 & 0.410 \\
\hline 25-29 (Ref.) & 1.000 & - & - & 1.000 & - & - & 1.000 & - & - \\
\hline $30-34$ & 1.297 & 0.192 & 0.079 & 1.239 & 0.220 & 0.228 & 1.514 & 0.404 & 0.120 \\
\hline$>34$ & 1.371 & 0.210 & 0.039 & 1.434 & 0.255 & 0.043 & 1.168 & 0.364 & 0.617 \\
\hline Unknown & 1.346 & 0.215 & 0.063 & 1.247 & 0.250 & 0.270 & 1.528 & 0.413 & 0.117 \\
\hline \multicolumn{10}{|l|}{$\begin{array}{l}\text { Previous birth } \\
\text { interval and } \\
\text { child survival }\end{array}$} \\
\hline $\begin{array}{l}\text { First birth or } \\
\text { uknown }\end{array}$ & 0.988 & 0.161 & 0.941 & 0.853 & 0.158 & 0.389 & 1.485 & 0.521 & 0.260 \\
\hline $\begin{array}{l}<19 \text { months and } \\
\text { alive (Ref.) }\end{array}$ & 1.000 & - & - & 1.000 & - & - & 1.000 & - & - \\
\hline $\begin{array}{l}<19 \text { months and } \\
\text { death }\end{array}$ & 1.240 & 0.379 & 0.481 & 0.855 & 0.320 & 0.675 & 3.314 & 1.853 & $\mathbf{0 . 0 3 2}$ \\
\hline $\begin{array}{l}>=19 \text { months } \\
\text { and alive }\end{array}$ & 0.812 & 0.135 & 0.212 & 0.736 & 0.140 & 0.108 & 1.139 & 0.404 & 0.715 \\
\hline $\begin{array}{l}>19 \text { months and } \\
\text { death }\end{array}$ & 0.868 & 0.234 & 0.599 & 0.665 & 0.216 & 0.210 & 1.805 & 0.912 & 0.242 \\
\hline \multicolumn{10}{|l|}{ Season } \\
\hline Winter (Ref.) & 1.000 & - & - & 1.000 & - & - & 1.000 & - & - \\
\hline Spring & 0.676 & 0.086 & 0.002 & 0.784 & 0.118 & 0.107 & 0.448 & 0.108 & 0.001 \\
\hline Summer & 0.741 & 0.095 & 0.019 & 0.674 & 0.109 & 0.015 & 0.824 & 0.175 & 0.361 \\
\hline Autumn & 0.689 & 0.088 & 0.004 & 0.681 & 0.107 & 0.014 & 0.691 & 0.155 & 0.099 \\
\hline \multicolumn{10}{|l|}{$\begin{array}{l}\text { Socioeconomic } \\
\text { Status }\end{array}$} \\
\hline $\begin{array}{l}\text { Professionals, } \\
\text { clerical and sales }\end{array}$ & 0.549 & 0.156 & 0.034 & 0.522 & 0.203 & 0.095 & 0.578 & 0.246 & 0.197 \\
\hline $\begin{array}{l}\text { Skilled and lower } \\
\text { skilled workers }\end{array}$ & 0.817 & 0.138 & 0.233 & 0.789 & 0.165 & 0.259 & 0.815 & 0.241 & 0.490 \\
\hline $\begin{array}{l}\text { Sharecroppers } \\
\text { and Farmers }\end{array}$ & 0.846 & 0.097 & 0.145 & 0.856 & 0.115 & 0.246 & 0.806 & 0.182 & 0.338 \\
\hline $\begin{array}{l}\text { Rural daily } \\
\text { wagers (Ref.) }\end{array}$ & 1.000 & - & - & 1.000 & - & - & 1.000 & - & - \\
\hline Unknown & 0.773 & 0.261 & 0.446 & 0.296 & 0.220 & 0.101 & 1.158 & 0.467 & 0.715 \\
\hline \multicolumn{10}{|l|}{$\begin{array}{l}\text { Mother's rural } \\
\text { status }\end{array}$} \\
\hline $\begin{array}{l}\text { Mother not in } \\
\text { rural work (Ref.) }\end{array}$ & 1.000 & - & - & 1.000 & - & - & 1.000 & - & - \\
\hline $\begin{array}{l}\text { Mother in rural } \\
\text { work }\end{array}$ & 1.266 & 0.164 & 0.069 & 1.247 & 0.196 & 0.161 & 1.303 & 0.300 & 0.251 \\
\hline \multicolumn{10}{|l|}{ Father's literacy } \\
\hline Sign (Ref.) & 1.000 & - & - & 1.000 & - & - & 1.000 & - & - \\
\hline No sig & 1.146 & 0.154 & 0.309 & 1.111 & 0.164 & 0.474 & 1.367 & 0.480 & 0.373 \\
\hline $\begin{array}{l}\text { Father not } \\
\text { present }\end{array}$ & 1.178 & 0.258 & 0.455 & 1.834 & 0.490 & 0.023 & 0.559 & 0.242 & 0.180 \\
\hline \multicolumn{10}{|l|}{ Period } \\
\hline 1900-1909 (Ref.) & 1.000 & - & - & 1.000 & - & - & & & \\
\hline 1910-1914 & 0.835 & 0.117 & 0.197 & 0.819 & 0.115 & 0.155 & & & \\
\hline $1915-1919$ & 0.867 & 0.143 & 0.387 & 0.761 & 0.135 & 0.125 & & & \\
\hline 1920-1929 & 0.717 & 0.092 & 0.010 & & & & 1.000 & - & - \\
\hline $1930-1939$ & 0.473 & 0.078 & 0.000 & & & & 0.666 & 0.118 & 0.021 \\
\hline \multicolumn{10}{|l|}{ Infant age } \\
\hline \multicolumn{10}{|l|}{$0-6$} \\
\hline $7-30$ & 0.161 & 0.021 & 0.000 & 0.146 & 0.024 & 0.000 & 0.201 & 0.047 & 0.000 \\
\hline
\end{tabular}




\begin{tabular}{|c|c|c|c|c|c|c|c|c|c|}
\hline $31-180$ & 0.032 & 0.004 & 0.000 & 0.029 & 0.004 & 0.000 & 0.039 & 0.009 & 0.000 \\
\hline $181-365$ & 0.028 & 0.003 & 0.000 & 0.025 & 0.004 & 0.000 & 0.036 & 0.008 & 0.000 \\
\hline $\begin{array}{l}\text { Number of } \\
\text { events }\end{array}$ & 467 & & & 314 & & & 153 & & \\
\hline $\begin{array}{l}\text { Number of } \\
\text { childbirths }\end{array}$ & 4,826 & & & 2,693 & & & 2,133 & & \\
\hline Log likelihood & $-2,448.5$ & & & $-1,599.4$ & & & -835.9 & & \\
\hline Days at risk & $1,633,110.5$ & & & $\begin{array}{r}895,184 . \\
5\end{array}$ & & & $\begin{array}{r}737,92 \\
6.0\end{array}$ & & \\
\hline
\end{tabular}

Sources: Birth, Marriage and Death Registers of the Municipality of Granarolo.

\section{Conclusion}

In this preliminary analysis, we explored the determinants of infant mortality during the first decades of the twentieth century using micro individual data and survivor modelling techniques. As a matter of fact, the scholar attention in Italy mainly focused on the nineteenth century and macro analysis, whereas a few studies considered the first decades of the twentieth century and used micro individual data. From this point of view, we believe that some regional and territorial variations in infant mortality could be better explained by using a micro level approach. So we focused on the period from 1900 to 1939 taking into account Granarolo, a rural village set very close the town of Bologna. Two main rural groups used to live in this community: the sharecroppers that could rely on a more stable agrarian contract and the daily wagers that lived in poorer and more precarious conditions. As previous historical studies already showed, from the early decades of the nineteenth century, this area was characterized by lower infant mortality levels, given the better environmental conditions and the progresses in the obstetrical cares.

After a longitudinal reconstruction of the infant biographies, several biological, demographic and socio-economic factors were assessed by means of Kaplan Meier estimates, Cox and the piecewise constant exponential models. We used Kaplan Meier curves and log rank tests as a preliminary descriptive approach. This explorative analysis demonstrated the influence of socio-economic factors (mother's and father's work) and season. A relevant period effect was also shown.

To control the possible compositional effects, we estimated separate Cox and piecewise constant exponential models for different periods. These analyses confirmed the effects of the socio-economic differences in infant mortality levels. We found that still in the first fourth decades of the twentieth century (1900-1939) rural daily wagers experienced lower levels in infant survivor, whereas the upper class registered significantly higher ones. The socio-economic status effect was not significant for the other two periods (1900-1919 and 1920-1939) probably because of the more limited number of cases. These estimates did not confirm the effects of the mother rural status, but showed a higher risk of infant death when the father was not present. Although infant survivor levels significantly increased after World War II, the effects of the season were still evident in the latter period from 1920 to 1939 with a higher mortality risk in winter than in summer. We also found 
significant bio-demographic effects for the sex of the neonate, multiple births and older ages of the mother. When the previous birth interval is shorter than 19 months and the last child died, the risk of infant death increases significantly, suggesting a correlation between the deaths of siblings. Considering the infant ages in the piecewise constant exponential model, it is also clear that the highest mortality risks were experienced in the first week of life.

\section{Bibliography}

Angeli Aurora, Lorenzo Del Panta and Alessandra Samoggia. "Aspetti del regime demografico in Emilia-Romagna tra XVIII e XIX secolo [Features of the demographic regime in Emilia-Romagna between XVII and XIX century]." In Le Italie demografiche. Saggi di demografia storica, eidted by Lorenzo Del Panta, 123-150. Udine: Università degli Studi di Udine, 1995.

Bellettini Athos. "Aspetti della transizione demografica italiana nel primo periodo postunitario" [Features of the Italian demographic transition during the first postunification period]. In Studi in onore di Luigi Del Pane, 769-805. Bologna: CLUEB, 1981.

Breschi Marco, Renzo Derosas and Matteo Manfredini. "Infant mortality in Nineteenth-century Italy: Interactions between ecology and society." In Population and Economy. From hunger to modern economic growth, edited by Tommy Bengtsson, and Osamu Saito. Oxford: University Press, 2000.

Breschi Marco, Massimo Esposito, Stanislao Mazzoni, and Lucia Pozzi. "The Sardinian Experience of the lowest Italian infant mortality at the turn of the twentieth century. True or false empirical evidence?" Annales de démographie historique 1 (2012): 63-94.

Calanca Daniela. "Famiglia e famiglie" [Family and families]. In Identikit del Novecento: conflitti, trasformazioni sociali, stili di vita [Identikit of the 20th century: Conflicts, social changes, lifestyles], edited by Sorcinelli Paolo, 97-179. Roma: Donzelli Editore, 2004.

Cazzola Franco. Storia delle campagne padane dall'Ottocento a oggi [History of the Po country sides from the 1800s until today]. Milano: Bruno Mondadori Editore, 1996.

Cox David R. " Regression model andlife tables." Journal of Royal Statistical Society, Series B (Methodological), 34 (1972), 187-220.

DaVanzo Julie, Hale Lauren, Razzaque Abdur and Rahman Mizanur. "The effects of pregnancy spacing on infant and child mortality in Matlab, Bangladesh: How they vary by the type of pregnancy outcome that began the interval." Population Studies 62, no 2(2008): 131-154.

Della Peruta Franco. "Infanzia e famiglia nella prima metà dell'Ottocento." Studi Storici 20, no 3 (1979): 473-491.

Del Panta Lorenzo. "Infant and child mortality in Italy, eighteenth to twentieth century: long-term trends and territorial differences". In Infant and Child Mortality in the Past, edited by Alain Bideau, Bertrand Desjardins, and Héctor Pérez Brignoli, 7-21. Oxford: Claredon, 1997.

Derosas Renzo. "The joint effect of maternal malnutrition and cold weather on neonatal mortality in nineteenth-century Venice: An assessment of the hypothermia hypothesis." Population Studies 63, no3 (2009): 233-251. 
Drevenstedt Greg. L., Eilleen Crimmins, Sarinnapha Vasunilashorn, and Caleb Finch. "The rise and fall of excess male infant mortality." Proceedings of the national academy of sciences of the United States of America 105, no13 (2008): 50165021.

Fleury Michel and Henry Louis H. Des registres paroissiaux à l'histoire de la population: Manuel de dépouillement et d'exploitation de l'état-civil ancien [Church records to the history of the population: Manual of count and exploitation of former civil status]. Paris: INED, 1956.

Friedman Michael. "Piecewise exponential models for survival data with covariates." The Annals of Statistics 10, no1 (1982):101-113.

Hong Rathavuth. "Effect of multiple birth on infant mortality in Bangladesh." Journal Paediatrics Child Health 42, no10 (2006): 630-635.

Istituto Centrale di Statistica. "Tendenze evolutive della mortalità infantile in Italia [Infant mortality evolving trends in Italy]." Annali di statistica, VIII (1975), 29, Roma.

Jacini Stefano. I risultati della Inchiesta Agraria (1884). La situazione dell'agricoltura e dei contadini italiani dopo l'Unità [Results from the agrarian survey (1884). The situation of agriculture and the Italian farmers' conditions after Unification]. Torino: Giulio Einaudi Editore, 1884.

Kaplan Edward L. and Meier Paul. "Nonparametric estimation from incomplete observations." Journal of the American Statistical Association 53 (1958): 457481.

Knodel John E. Demographic behavior in the past: A study of fourteen German village populations in the Eighteenth and Nineteenth centuries. Cambridge: Cambridge University Press, 1988.

Kramer Karen L. and Lancaster Jane B. "Teen motherhood in cross-cultural perspective." Annals of Human Biology 37, no5 (2010):613-628.

Mantel Nathan and Haenszel William. "Statistical aspects of the analysis of data from retrospective studies of disease." Journal of the National Cancer Institute, 22 (1959): 719-748.

Mitchell Brian R. European Historical Statistics 1750-1970. London: McMillan Press, 1975.

Palazzi, Maura. "Famiglia, lavoro e proprietà: le donne nella società contadina fra continuità e trasformazione" [Family, labor and property: women in rural society between continuity and change]. Annali dell'Istituto Alcide Cervi 12 (1990): 2580.

Pozzi Lucia. "The determinants of infant and childhood mortality: a complex tangle in the historical research." In Società Italiana di Statistica, Atti della XLI Riunione Scientifica, Milano 5-7 giugno. Padova: CLEUP, 2002, 77-86.

Scalone Francesco, Agati Patrizia, Angeli Aurora and Donno Annalisa. "Microanalisi delle tendenze nella mortalità infantile a Granarolo dell'Emilia tra il XIX e il XX secolo [Micro Analysis in Infant Mortality Trends in Granarolo between XIX and XX Century]." In Mortalità e stato di salute dalla nascita alla prima adolescenza. Indagini micro in Italia. Secoli XIX-XX, edited by Marco Breschi and Lucia Pozzi, 51-79. Udine, Forum, 2013.

Villani Pasquale. "La pluriattività negli spazi rurali: ricerche a confronto. Introduzione [Pluriactivity in rural areas: researches comparisons. Introduction]." Annali dell'Istituto Alcide Cervi 11, (1989): 11-22.

Ward Peter. "Perinatal mortality in Bologna, 1880-1940." In The Determinants of Infant and Child Mortality in Past European Populations, edited by Marco Breschi and Lucia Pozzi, 213-230. Udine-Sassari: Forum, 2004. 
World Health Organization (WHO). Neonatal and perinatal mortality. Country, regional and global estimates. France, 2006.

Wrigley Edward A., Davis Ros S., Oeppen James E., and Schofield Roger S. English population history from family reconstitution 1580-1837. Cambridge: Cambridge University Press, 1997. 